\title{
熱収支及び土㙵水分を考慮した地表面地物 要素毎の蒸発散モデルの構築と実流域への適用 MODELING THE EVAPOTRANSPIRATION OF INDIVIDUAL LAND-SURFACE FEATURES CONSIDERING HEAT BALANCE AND SOIL MOISTURE, AND ITS APPLICATION TO AN ACTUAL RIVER BASIN
}

\author{
古賀達也 1 ・河村明 2 ・天口英雄 3 \\ Tatsuya KOGA, Akira KAWAMURA and Hideo AMAGUCHI \\ 1正会員 工修（株）建設技術研究所（ $\bar{T} 103-8430$ 東京都中央区日本橋浜町3-21-1） \\ 2 正会員 工博 首都大学東京教授 都市環境科学研究科（广192-0397 東京都八王子市南大沢1-1） \\ 3 正会員 博(工) 首都大学東京助教 都市環境科学研究科（广192-0397 東京都八王子市南大沢1-1）
}

In this study, an evapotranspiration model that can express the amount of evapotranspiration accounting for differences in soil moisture and penetration characteristics of individual land-surface features is proposed. The model is composed of two components; the infiltration area model based on SMPT model to represent the infiltration process of the surface soil, and the impervious area model considering depression storage in impervious areas. Furthermore, the infiltration area model takes into account the state of the soil moisture and differences in land use of the land-surface features, and estimates the latent and sensible heat using a heat balance equation based on the bulk formula. The model was applied to the highly urbanized upstream basin of Kanda River, and the impacts of differences in land use on the spatial distribution of evapotranspiration and land surface temperature was analyzed.

Key Words : heat balance, evapotranspiration, individual land-surface features, soil moisture, advanced GIS delineation

\section{1. はじめに}

都市流域では, 山地流域とは異なり, 雨水が浸透し ない建物・道路などの人工的な構造物と公園・グラウン ドなどの浸透域が複雑に分布している．また，道路の側 溝や雨水・下水道管路など河川に至る流出経路には，貯 留浸透施設や治水施設などが整備されており，その形態 は絶えず変化しているため, 都市流域の雨水流出プロセ スは非常に複雑となっている.

都市流域の水循環過程を解明するには，雨水を受ける 地表面の浸透特性が都市化の影響によりどのような状態 にあるのか，寸なわち浸透・不浸透域の分布状況を正確 に表現可能であることが重要であり，このような土地利 用情報を入力データとして利用できる分布型水循環モデ ルが必要である．また，都市域における地下水浸透過程 を解明するためには，土地利用情報に基づいた蒝発散量 が算定可能なモデルが重要である.さらに，行政部局に よる都市流域におけるヒートアイランド対策として屋上 緑化等を行う場合の施策評価において, 効果検証が可能
なモデルが望まれている，そのためには，道路や建物の 建設状況など，具体的な都市化の進展状況をできる限り 忠実にモデル化することが可能で，屋上緑化等による蒸 発散量の変化に伴う気温上昇抑制効果を個々に検証・予 測できるシミュレーションモデルの開発が望まれている。

浸透域において蒸発散量は明らかに土䁃水分の影響を 受けるが，蒸発散量の計算に一般的に用いられるHamon 式1)，Thornthwaite式)等を用いた手法は，気象条件のみ から可能蒸発散能を推定し, 経験的な係数を乗じること により蒸発散量を算定する方法であり, 蒸発散に土壌水 分は考慮されていない．また土壌水分は流出にも影響を 及ぼすため，これらの相互関係を十分に考慮した上で蒸 発散量が推定される必要があるが，上記の式では土地利 用の浸透・不浸透域における蒸発散量の違いや，浸透域 における土地利用区分毎の土㙥水分量が蒸発散一与える 影響について考慮できない，これに対し竹下らは，集中 型モデルを用いて土地利用を考慮したHamon式による蒸 発散モデルの構築を行っている3)が，これまで地表面地 物要素毎の土地利用状況を反映した蒝発散量の違いを表 
現できるモデルは見あたらない，また，Hamon式などは 熱収支的側面についても考慮しておらず，地表面温度の 算定を精度良く行うためには，熱収支式を用いて求まる 潜熱・顕熱により蒸発散量の推定を行う必要がある4).

都市域のモデル作成に用いるデータについては, 近年 GISデータの整備が目覚ましい，これまで，都市流域は 人工的要素を含むため詳細な空間情報の記述が容易では なかったが，これらの地物データを忠実に表現可能な心゙ クター型土地利用情報を用いることで, 特定の建物, 道 路といった詳細な空間情報を抽出することが可能となっ た.しかし，現在利用可能な基礎的地物データGISには， 浸透特性に基づいた林地, 緑地, グラウンドなどの土地 利用種別の情報が含まれていない，これまで著者らは基 礎的地物データGISをベースに，独自に調査した浸透域 に関する情報を新たに組み込むことにより，都市を形成 している土地利用を浸透特性で分類するGISを構築して きている5). そして，分布型洪水流出モデルに適用でき る地物形状を忠実に反映したGISデータを「高度な地物 データGIS」と定義し, 神田川上流域を対象として土地 利用の詳細な判別を行い，その高度な地物データ GISを 構築する方法を述べているの. また，この高度な地物 データGISを用いて家屋, 道路, 緑地等の個別地物を忠 実に反映した都市流域洪水解析モデル(TSRモデル： Tokyo Storm Runoff Model)を提案している7,8).

本論文では，高度な地物データGISを用いて地表面を 浸透域と不浸透域に分類し, 地表面地物要素毎の浸透特 性と土㙥水分量の違いによる蒸発散量を熱収支を考慮し て表現できる蒸発散モデルを構築した．以下，本モデル をTET(Tokyo Evapotranspiration) モデルと呼ぶ. TETモ デルの構築にあたり，まず表層土壤への浸透過程を表現 するモデルとしてSMPTモデル(Soil Moisture Parameter Tank Model) ${ }^{9}$ による浸透域モデルを構築し，不浸透域に おいては窪地販留を考慮した不浸透域モデルを構築した。 浸透域に対しては, 地表面地物要素毎の土地利用の違い および土壌水分量の状態を考慮し，バルク式による熱収 支式を用いて潜熱・顕熱を算定できるモデルとした．さ らに，算定された潜熱・影熱を用いて地表面地物要素毎 の蒸発散量時系列と同時に地表面温度変化を表現できる モデルとした．次にTETモデルを高度に都市化の進展し た神田川上流域に適用し，2011年の1年間の地表面地物 要素毎の日蒸発散量および日平均地表面温度の算定を 行った. これより, 流域の年単位の蒸発散量を算定し, 実測の年蒸発散量との比較によりTETモデルの妥当性を 確認するとともに, 神田川流域内の地表面地物要素の土 地利用種別の違いが蒸発散量の空間分布, および地物表 面温度の空間分布に及ぼす影響について評価した.

\section{2. 蒸発散モデルの構築}

（1）熱収支式による潜熱，顕熱評価モデル

地表面の熱収支式の基礎方程式である式(1)を用いて、
熱収支式により潜熱，顕熱を評価し，求められた潜熱よ り蒸発散量の推定を行う ${ }^{10}$.

$$
R_{n}=H+\ell E+G
$$

ここで, $R_{n}$ : 正味放射量 $\left(\mathrm{W} / \mathrm{m}^{2}\right), \quad \ell E$ : 潜熱伝達量 $\left(\mathrm{W} / \mathrm{m}^{2}\right), \quad H$ : 顕熱伝達量 $\left(\mathrm{W} / \mathrm{m}^{2}\right), G$ : 地中熱伝達量 $\left(\mathrm{W} / \mathrm{m}^{2}\right)$ である.また $R_{n}$ は 放射収支では以下の式で表さ れる.

$$
R_{n}=(1-\alpha) R_{\text {glob }}+L_{s k y}-L_{s o i l}
$$

ここで， $\alpha$ : 地表面の反射率(アルベド), $R_{g l o b}$ : 地表 面での全天日射量 $\left(\mathrm{W} / \mathrm{m}^{2}\right), L_{\mathrm{sl} y}$ : 大気放射量 $\left(\mathrm{W} / \mathrm{m}^{2}\right)$, $L_{\text {soil }}$ : 地表面放射量 $\left(\mathrm{W} / \mathrm{m}^{2}\right)$ である. $R_{\text {glob }}$ は大気圈外日射量 $R_{\text {out }}$ と日照時間 $n$, 可照時間 $N$ とから以下の様に求められ る.

$$
R_{\text {glob }}=R_{\text {out }}(0.25+0.5 n / N)
$$

ここで, $R_{\text {out }}$ : 大気圈外日射量 $\left(\mathrm{W} / \mathrm{m}^{2}\right), n$ : 日照時間 $(\mathrm{h})$, $N$ : 可照時間(h)である. $N$ は測定地点の緯度, 計算する 日の積算日数(1月1日から積算した日数)等から計算され る.

地表面放射 $L_{\text {soil }}$ はステファン・ボルツマンの法則に従 い，地表面温度 $T_{S}$ から計算される.

$$
L_{\text {soil }}=\varepsilon \sigma T_{S}^{4}
$$

ここで， $\sigma$ : ステファン・ボルツマン定数 $(5.67 \times 10-8$ $\left.\mathrm{W} / \mathrm{m}^{2} \cdot \mathrm{k}^{2}\right), T_{S}$ : 地表面温度 $(\mathrm{K}$ : ケルビン $), \varepsilon$ : 射出率 $(\mathrm{c}$ 地表面ではほぼ1.0)である。

式(4)より $L_{\text {soil }}$ は地表面温度が $10^{\circ} \mathrm{C}$ 変化すると $50 \mathrm{~W} / \mathrm{m}^{2}$ 程 度異なるため, それに伴い $R_{n}$ は近傍であってもおよそ $50 \mathrm{~W} / \mathrm{m}^{2}$ 程度の差が生じる． $R_{n}$ は通常各所で観測されて いないため, 式(3)の代わりに入力放射 $R\left(=R_{n}+L_{\text {soil }}\right)$ を用い た熱収支式(5)を使う。

$$
R=(1-\alpha) R_{\text {glob }}+L_{s k y}
$$

一方Rは熱収支式(1)に式(4)を考慮すると式(6)となる.

$$
R=\varepsilon \sigma T_{s}^{4}+H+\ell E+G
$$

$R$ と $L_{s k y}$ は数 $\mathrm{m}$ 数 $\mathrm{km}$ 範囲なら場所によって大きく変 化しないため, 熱収支式としては式(6)が通常用いられて いる11). 式(6)の左辺 $R$ は観測值であるため既知である.

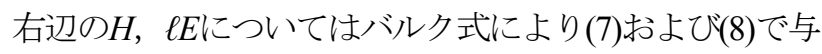
えられる.

$$
\begin{gathered}
H=c_{P} \rho C_{H} U\left(T_{s}-T\right) \\
\ell E=\ell \rho \beta C_{H} U\left(q_{S A T}-q\right)
\end{gathered}
$$

ここに, $c_{P}$ : 空気の定圧比熱 $(1005 \mathrm{~J} / \mathrm{kg} / \mathrm{K}), \rho:$ 空気密 度 $\left(\mathrm{kg} / \mathrm{m}^{3}\right), C_{H}$ : 顕熱輸送のバルク係数(無次元), $U$ : 観 測地点の風速, $T$ : 大気気温 $(\mathrm{K}), \ell$ : 水の気化潜熱 $(2.50 \times$ $106 \mathrm{~J} / \mathrm{kg}$ )， $\beta$ : 蒸発効率(無次元)， $q_{S A T}: T_{S}$ に対寸る飽和 比湿(無次元), $q$ : 大気の比湿(無次元)である. $\rho$ につい ては次式より求める ${ }^{12)}$. 


$$
\rho=1.293 \frac{273.15}{273.15+T} \times \frac{p}{1013.25}\left(1-0.378 \frac{e}{p}\right)
$$

ここに, $p:$ 気圧 $(\mathrm{hPa}), e$ :水蒸気圧 $(\mathrm{hPa})$ である. なお, 式(9)での大気気温 $T$ 単位は $\left({ }^{\circ} \mathrm{C}\right)$ である. $p$ については 観測される值であり, Tの時のeは観測值の湿度と $T$ より 算定可能な飽和水蒸気圧より算定できる.

$C_{H} U$ は顕熱輸送の交換速度と呼ばれ, 風速 $U$ と安定度 の関数であり, 観測地点の高度および風速を用いて算定 され，土地利用毎に算定時の定数が設定されている ${ }^{13)}$. $\beta$ は地表面の蒸発のしやすさを表す蒸発効率(湿潤度と呼 ぶこともある)であり0 1の值をもつものであり，この $\beta$ を後述の地表面地物要素毎の土地利用と土壤水分量加 逐次設定することにより，潜熱および顕熱に地表面地物 要素毎の土地利用と土㙥水分量を考慮するものとした. 土地利用状況によって異なる変数としては上記の他， $a$ についてである. まとめると顕熱輸送の交換速度 $C_{H} U$, 蒸発効率 $\beta$ おびアルベド $\alpha$ 土地利用の違いを表現す る変数となる.

$q_{S A T}$ は $T_{S}$ の関数である飽和水蒸気圧 $e_{S A T}$ を用いて式(10) で与えられる14).

$$
q_{S A T}=0.622 e_{S A T} /\left(p-0.378 e_{S A T}\right)
$$

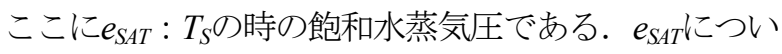
てはTetensの式(11) ${ }^{15)}$ を用いて算定した. 定数については 水上を想定した定数を用いた。 なお，式(11)での地表面 温度 $T_{S}$ の単位は( $\left.{ }^{\circ} \mathrm{C}\right)$ である.

$$
e_{S A T}=6.11 \times 10 \frac{7.5 T s}{\left(T_{S}+237.3\right)}
$$

これらより,式(8)の $q_{S A T}$ は $T_{S}$ の関数となる. 以上まとめ ると式(6)の左辺は式(5)より既知であり，式(7),(8)は全て

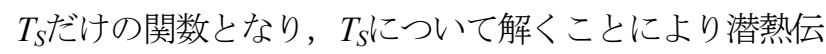
達量 $\ell E$ と顕熱伝達量 $H$ について求めることとなる.

Gは陸地面において毎日同じような気象条件が続いて いる場合は日中・夜間でプラス・マイナスとなる，本論 文では日平均状態を対象とするため, $G$ については 0 と している.

\section{（2） SMP Tモデルによる土壌水分量評価}

実現象の蒸発散量は土地利用や土袞の水分状態，およ び気象条件に影響されている. そのため, 図-1に示寸よ うな地表面地物要素の浸透特性と土壌水分量の違いによ る蒸発散量を表現できる蒸発散モデルを構築すべく, ま ず表層土壌への浸透過程を表現するモデルとしてSMPT モデル9による浸透域モデルを構築し，不浸透域におい ては宔地貯留を考慮した不浸透域モデルを構築すること とした. SMPTモデルにおける浸透域モデルは表層土壌

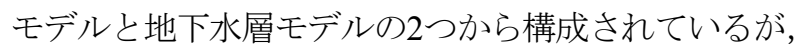
本論文では著者らの従来のモデル4によるものとし，表 層土㙵モデルのみを採用し簡易な表層土壌浸透モデルと している. 表層土壌浸透モデルからの浸透量は, 系外に

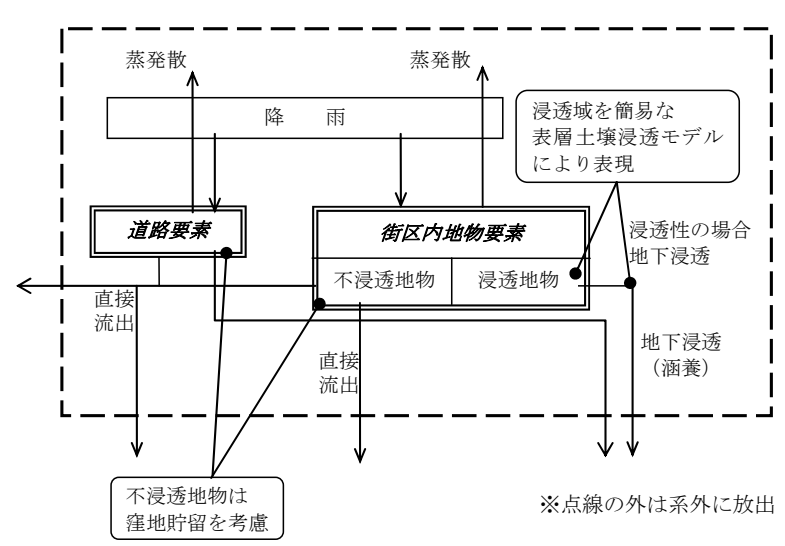

図-1＼cjkstart本論文における蒸発散モデルの概念

放出するものとした.

\section{(3) 蒸発散モデルの構築}

土地利用毎の蒸発散係数, 土壌水分量からバルク式に おける蒸発のしやすさを表寸蒸発効率 $\beta$ 算定し, これ を用いて潜熱，顕熱を算定することにより土地利用区分 の違いによる土壌水分を考慮した烝発散量の推定を行う モデルを構築する.

式(8)における蒝発効率 $\beta$ は可能蒸発散能と実蒸発散量

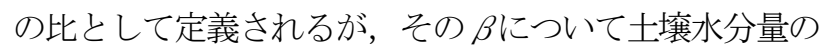
関数 $(0 \sim 1)$ とし, 土壤水分率 $\lambda_{w}=0$ のとき $\beta=0, \lambda_{w}=1$ のと き $\beta=1$ となるような関係式を竹下らが提案している関係 式3を参考として式(12)で表現する。この $\beta$ を用いて土地 利用区分毎の蒸発散係数, 最大保水量に対する土㙵水分 量を考慮することにより，土地利用種別の違いおよび土 袞水分量の違いによる蒸発散量を $\beta$ にる表現する蒸発 散モデルとした.

$$
\beta=1-\frac{2}{1+\exp \left(-k \times \lambda_{x}\right)}
$$

ここに， $k$ :土地利用種別毎に設定する蒸発散係数(無 次元), $\lambda_{x}$ : 土壤水分係数である. 土袞水分係数 $\lambda_{x}$ は土壌 水分率为を用いて以下の式で表現する.

$$
\lambda_{x}=1-\frac{1}{\left(1-\lambda_{w}\right)}
$$

ここに, $\lambda_{w}$ : 土壌水分率(飽和土壤水分量 $S_{s a t}$ に対する 土壤水分量 : 無次元)

本論文では，SMPTモデルによる簡易な表層土壌浸透 モデルをもとに, 飽和土壤水分量 $S_{\text {sat }}$ と計算ステップ毎 の土壤水分量 $S(t)$ から土袞水分率 $\lambda_{w}$ を算定することによ り, 蒸発効率 $\beta$ を算定するモデルとした. また, 対象流 域内では高度な地物データ GISを20の土地利用種別に分 類しているが10，浸透域については土地利用種別毎の蒸 発散係数 $k$, 飽和土袞水分量 $S_{\text {sat }}$ を設定することにより, 土地利用種別毎の蒸発散量の算定が可能なモデルとした。 不浸透地物においては，著者らの従来のモデル4)用 いることとし， $\beta=1$ の場合の蒸発散量である可能蒸発散 能 $E_{p}(t)$ に補正係数の0.6(鴨下ら ${ }^{17)}$ を参考に設定)を乗じた 
ものと窪地貯留の水量を比較し, 窪地貯留の水量を上限 として実蒸発散量 $E(t)$ とした.

\section{3． 神田川上流域の流域特性}

\section{（1）神田川上流域の概要}

本論文では，図-2に示寸神田川の井の頭池から善福寺 川合流点までの上流域約 $11.5 \mathrm{~km}^{2}$, 流路延長約 $9 \mathrm{~km}$ 対象 流域として設定した．図-3に対象とする神田川上流域の 高度な地物データGISを示すが，本流域の全地物を20の 土地利用種別に分類している.

\section{（2）高度な地物データ GI Sの特性}

表-1に高度な地物データ GISによる面積および面積率 を示すが，面積率では間地と建物がそれぞれ約 $30 \%$ 占 めており最も多く，次いで道路の約16\%の順となってい る.

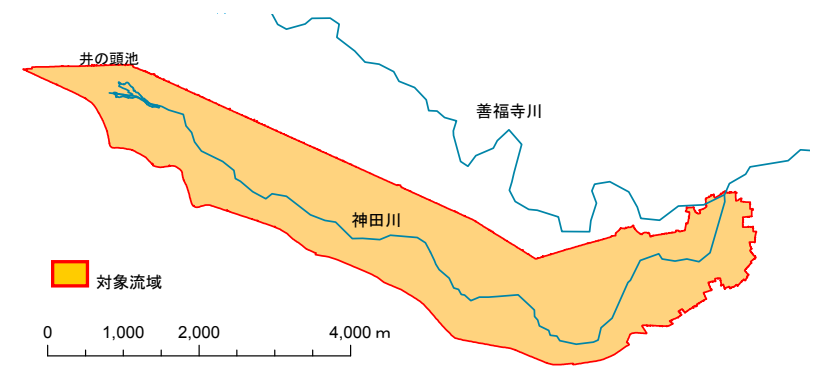

図-2＼cjkstart対象とした神田川上流域位置図

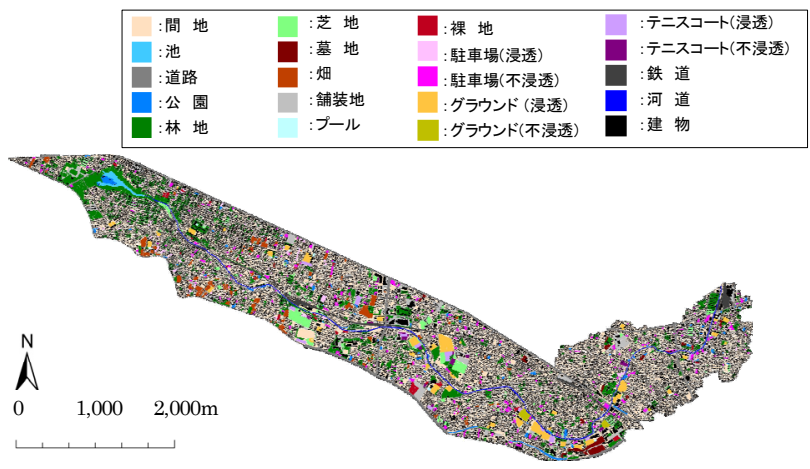

図-3＼cjkstart神田川上流域の高度な地物データGIS

表-1 土地利用種別毎面積, 面積率, 蒸発散パラメータ

\begin{tabular}{|c|c|c|c|c|c|c|c|c|c|c|c|c|}
\hline № & $\begin{array}{c}\text { 土地利用 } \\
\text { 種別 }\end{array}$ & 浸透 & $\begin{array}{l}\text { 面積 } \\
\left(\mathrm{km}^{2}\right)\end{array}$ & $\begin{array}{l}\text { 面積 } \\
(\%) \\
(\%) \\
\end{array}$ & $\begin{array}{c}\text { 飽和 } \\
\text { 土壤 } \\
\text { 水量 } \\
(\mathrm{mm})\end{array}$ & $\begin{array}{c}\text { 最小 } \\
\text { 䎥水 } \\
(\mathrm{m} \text { 量) } \\
(\mathrm{m})\end{array}$ & $\begin{array}{l}\text { 地下水 } \\
\text { 婳羑 } \\
(1 / \text { 数 } \\
(1 / \mathrm{s})\end{array}$ & $\begin{array}{l}\text { 初期 } \\
\text { (mm } \\
\text { (mm) }\end{array}$ & $\begin{array}{l}\text { 最大 } \\
\text { 丞発 } \\
\text { 散比 }\end{array}$ & $\begin{array}{l}\text { 蒸㪘 } \\
\text { 係 }\end{array}$ & $\begin{array}{l}\text { アル } \\
\text { ベド }\end{array}$ & $\begin{array}{l}\text { 定数が } \\
\text { 値の } \\
\text { 分※ }\end{array}$ \\
\hline 1 & 建 物 & 不浸透 & 3.38 & 29.39 & - & - & 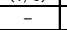 & - & - & - & 0.12 & 区分5 \\
\hline 2 & 駐車場(浸透) & 浸透 & 0.06 & 0.52 & 92 & 74 & 0.8 & 64 & 1.0 & 0.34 & 0.10 & 区分3 \\
\hline 3 & 駐車場 (不浸透) & 不浸透 & 0.21 & 1.80 & - & - & - & - & - & 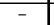 & 0.12 & 区分5 \\
\hline 4 & グラウンド (浸透) & 浸透 & 0.23 & 1.96 & 92 & 74 & 0.8 & 64 & 1.0 & 0.34 & 0.10 & 区分3 \\
\hline 5 & グラウルド (不浸透) & 不浸透 & 0.02 & 0.20 & -1 & - & -1 & -1 & 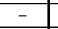 & 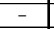 & 0.12 & 区分5 \\
\hline 6 & 林 地 & 浸透 & 1.04 & 9.05 & 138 & 110 & 0.8 & 97 & 1.2 & 4.38 & 0.15 & 区分1 \\
\hline 7 & 芝 地 & 浸透 & 0.17 & 1.49 & 92 & 74 & 0.8 & 64 & 1.0 & 0.34 & 0.10 & 区分3 \\
\hline 8 & 畑 & 浸透 & 0.19 & 1.64 & 104 & 83 & 0.8 & 73 & 1.0 & 0.55 & 0.23 & 区分2 \\
\hline 9 & 公 園 & 浸透 & 0.10 & 0.91 & 92 & 74 & 0.8 & 64 & 1.0 & 0.34 & 0.10 & 区分3 \\
\hline 10 & 墓 地 & 浸透 & 0.07 & 0.61 & 92 & 74 & 0.8 & 64 & 1.0 & 0.34 & 0.10 & 区分3 \\
\hline 11 & 舗装地 & 不浸透 & 0.38 & 3.30 & - & - & - & - & - & - & 0.12 & 区分5 \\
\hline 12 & 鉄 道 & 不浸透 & 0.15 & 1.30 & - & - & - & - & - & - & 0.12 & 区分5 \\
\hline 13 & 間 地 & 50\%漫透 & 3.43 & 29.83 & 92 & 74 & 0.8 & 64 & 1.0 & 0.34 & 0.10 & 区分3 \\
\hline 14 & 宁ニスコート(浸透) & 浸透 & 0.05 & 0.47 & 92 & 74 & 0.8 & 64 & 1.0 & 0.34 & 0.10 & 区分3 \\
\hline 15 & テテニスコート (不浸透) & 不浸透 & 0.03 & 0.26 & - & - & - & - & - & - & 0.12 & 区分5 \\
\hline 16 & 裸 地 & 浸透 & 0.05 & 0.46 & 80 & 64 & 0.8 & 56 & 1.0 & 0.13 & 0.10 & 区分4 \\
\hline 17 & プール & 不浸透 & 0.01 & 0.10 & - & - & - & - & - & - & 0.12 & 区分5 \\
\hline 18 & 道路 & 不浸透 & 1.79 & 15.52 & - & - & - & - & - & - & 0.12 & 区分5 \\
\hline 19 & 池 & 不浸透 & 0.04 & 0.31 & 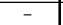 & - & - & - & - & - & 0.12 & 区分5 \\
\hline 20 & 河道 & 不浸透 & 0.10 & 0.87 & - & - & - & - & - & - & 0.12 & 区分5 \\
\hline
\end{tabular}

\section{4. 神田川上流域への適用}

\section{(1) 計算条件}

本論文では，2011年の1月～12月の1年間を対象に，今 回提案したモデルを用いて日単位の潜熱，顕熱の算定お よびそれらを用いて算定ができる，個別地物の地表面温 度および蒸発散量の解析を行った. バルク式に用いる日 平均気温, 風速については対象流域近傍の気象庁アメダ ス「府中」における観測值を用いた4)。全天日射量につ いては府中観測所では観測されていないため，「東京」 における観測值を用いた，大気放射量については，近藤 の提案する手法 ${ }^{18}$ により算出した．本論文では地物毎の 蒸発散量および地表面温度の相対比較を目的としている ため，全地物の気象条件は府中，および東京で観測され た観測值を用いて一様に与えることとし， $\beta$ の違いによ る蒸発散量の感度を見ることとする.

高度な地物データGISでは，表-1に示す通り20の土地 利用種別に分類しており，それぞれに浸透域または不浸 透域の設定を行っている. なお間地の浸透特性について は50\%浸透と設定しているため，残り50\%の面積は不浸 透域として扱った。これらの土地利用種別において，土 壤水分法による蒸発散モデル適用のために蒸発散係数 $k$, 飽和土畩水分量 $S_{\text {sat }}$ を設定する必要がある。浸透域につ いての上記パラメータについては，土地利用種別毎の実 測蒸発散量を用いたキャリブレーションにより設定する ことが望ましいが，ここでは流域全体の蒸発散量が妥当

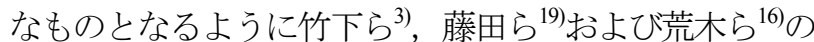
值を参考として，20の土地利用種別のうち浸透域である 10種の土地利用種別についてパラメータを設定した。な お，土地利用種別は10種存在するが大きくは4区分され， それぞれの区分内の土地利用種別ごとのパラメータは同 様とした。 区分 1 は林地のみ，区分2は畑のみ，区分3は 駐車場(浸透)，グラウンド(浸透)，芝地，公園，墓地， テニスコート(浸透), 間地の $50 \%$ 面積, 区分4は裸地とし た. また，不浸透域である建物，駐車場(不浸透), グラ ウンド(不浸透), 舗装地，鉄道，間地の $50 \%$ 面積，テニ スコート(不浸透)，プール，道路，池，河道については 区分5とし，直接流出発生高(窪地貯留高)は一般的な值 ${ }^{20}$ を採用し $2 \mathrm{~mm}$ と設定した。 また，アルベドについても同 様に5区分とし，土地利用種別毎に一般的な值 ${ }^{21)}$ を採用 した.

\section{(2) 計算結果}

上記の計算条件をもとに，対象流域である神田川上流 域において2011年の1年間の日単位計算による地物毎の 蒸発散量の算定を行った結果を図-4に示す。図-4には, 入力条件として与えた府中観測所の日雨量, 日平均気温 の時系列変化を示している．浸透域については蒸発散モ デルパラメータが同值であれば同様の蒸発散量であるた め，図-4には浸透域4区分のそれぞれの代表土地利用種 


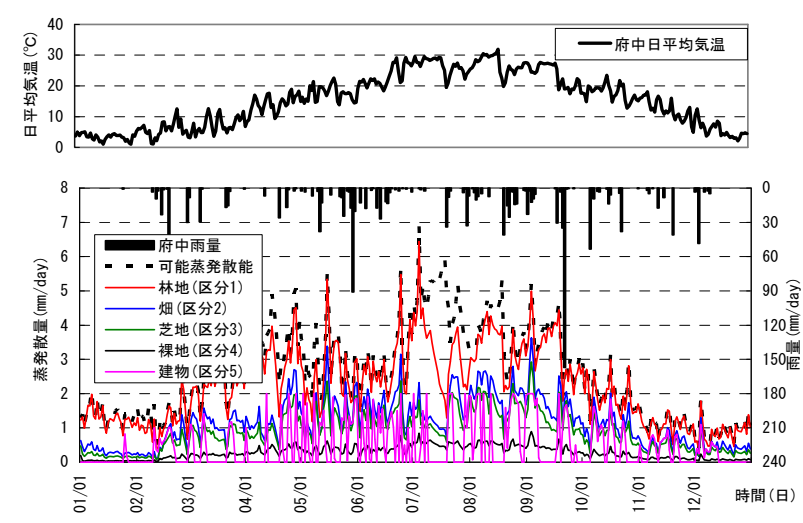

図-4 土地利用種別毎の蒸発散量

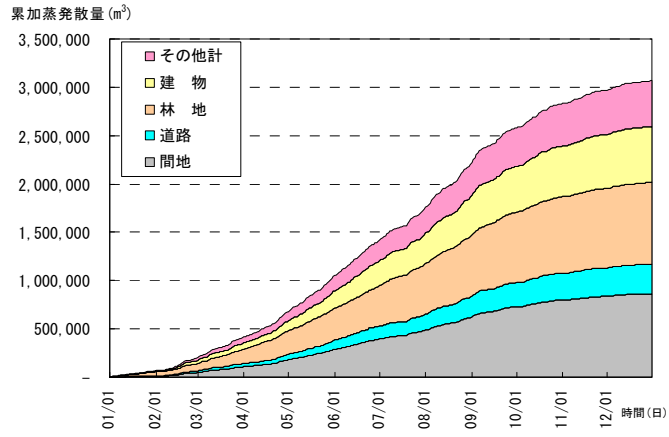

図-5 土地利用種別毎の蒸発散ボリューム累加図

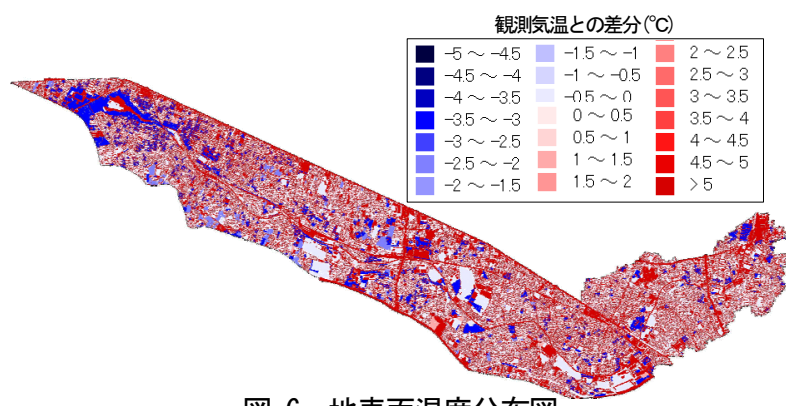

図-6 地表面温度分布図

別として林地(区分1), 畑(区分2), 芝地(区分3), 裸地(区 分4)の4種と不浸透域の代表土地利用として建物(区分5) の5土地利用種別の蒸発散量時系列を示している.また, 熱収支より算定される区分 3 の可能蒸発散能についても 併記している. 府中観測所の日平均気温は，7月～8月が 約 $30^{\circ} \mathrm{C}$ と゚ークであり, 熱収支式より算定される可能蒸 発散能は最大で約 $7 \mathrm{~mm} / \mathrm{day}$ である. 図-4より7月中旬では 可能蒸発散量に対して林地の蒸発散量は可能蒸発散能に 対して小さい.これは7月は降雨が少なく蒸発により土 壌水分が減少していくことにより，蒸発効率 $\beta$ が小さく なっていくことによるものである，不浸透域である建物 については，窪地貯留高が $2 \mathrm{~mm}$ でありそれ以上の降雨が 発生した場合は直接流出となるため, 最大蒸発散量は $2 \mathrm{~mm} /$ day となっている。年間の総蒸発散量は, 林地 $817 \mathrm{~mm} /$ year, 畑 $427 \mathrm{~mm} /$ year, 芝地 $333 \mathrm{~mm} /$ year, 裸地 $103 \mathrm{~mm} /$ year, 建物 $170 \mathrm{~mm} /$ yearとなっており, 裸地が建物 より小さい結果となっている，建物等の不浸透域は窪地 貯留の水量を上限として最大 $2 \mathrm{~mm} / \mathrm{day}$ が蒸発すると仮定
している. 一方裸地は砂礫地，荒地等の土地利用であり， 土壌水分率が $80 \%$ 程度まで蒸発効率 $\beta$ が可能蒸発散能に 対し2割以下となっているため, 建物より蒸発散量が小 さくなっている. なお，裸地の土地利用面積率は $0.5 \%$ と 微少なため全体の蒸発散量に占める影響は小さい.

図-5には，土地利用種別毎の蒸発散ボリュームの累加 図を示す。単位面積当たりの蒸発散量が同值でも土地利 用種別毎に対象流域における面積が異なっているため, それに伴い蒸発散ボリュームは変化することとなる。こ こでは，蒸発散ボリュームが大きい間地，道路，林地， 建物の4種の土地利用種別とその他 16 種別は合計とし計5 種を示している. 間地, 道路，林地，建物の4土地利用 で，全地物の合計蒸発散ボリュームの $85 \%$ を占めており， その内訳はそれぞれ間地(28\%)，道路(10\%)，林地(28\%), 建物(19\%)となっている。道路および建物は不浸透域で あり単位面積あたりの年間蒸発量は $170 \mathrm{~mm} / \mathrm{year}$ とさい が，それぞれの面積率が道路(16\%), 建物(29\%)と大きい ため結果として蒸発散ボリュームが大きくなっている. 間地についても単位面積あたりの年間蒸発散量 $252 \mathrm{~mm} /$ yearであるが面積率が $29 \%$ と大きくこのような結 果となっている。一方, 林地については面積率は $9 \%$ と 小さいが，単位面積あたりの年間蒸発散量が $817 \mathrm{~mm} / \mathrm{year}$ と大きいため結果として蒸発散ボリュームが大きな割合 を占めることとなっている.

\section{5. 考察}

\section{（1）実測値との比較}

以上の結果より, TETモデルで算定した蒸発散量の妥 当性について確認してみる。 まずは林地の蒸発散量につ いてであるが日本の森林の一般的な蒸発散量は500〜 1,000mm/yearのオーダーであるのに対し, TETモデルで 算定した林地の蒸発散量は982mm/yearであり，概ね妥当 な結果が得られていると考えられる. 次に神田川上流域 の全体の水収支の観点から推定を試みる。府中の2011年 の年間総雨量は1,428mmであり, 流域全体の総雨量ボ リュームに換算すると16,825千 $\mathrm{m}^{3}$ である. これに対し, TETモデルで得られた全地物からの年間総蒸発散ボ リュームは3,068千 $\mathrm{m}^{3}$ であるため蒸発散比は約 $20 \%$ とな る. 一方，神田川全流域の流域平均雨量と年間蒸発散量 は1,512mm/yearおよび231mm/year程度 ${ }^{22}$, 東京都全域の 年間雨量と蒸発散量は1,405mm/yearおよび412mm/year程 度 ${ }^{23)}$ とっており, 雨量に対する蒸発散比は $15 \%$ おび 29\%程度のオーダーであると考えられ，TETモデルで得 られた蒸発散比 $20 \%$ は妥当な值となっている.これより, TETモデルでは従来評価されていなかった土地利用毎の 浸透特性および土㙋水分量を考慮した蒸発散量の推定が 可能となると考えられる. 以上の結果は表-1に示す蒸発 散モデルパラメータによる結果であり妥当な蒸発散量が 算定されているが，より詳細な地物毎の蒸発散モデルパ ラメータについては実測蒸発散量とのキャリブレーショ 
ンが必要である.

\section{（2）地表面温度の空間分布}

TETモデルでは，個別地物毎の潜熱・顕熱輸送量およ び蒸発散量の他に，地物地表面温度の推定が可能である.

図-6には夏場の8月18日における地物地表面の観測気 温との差分分布を示している. 図-4より林地の蒸発散量 が最も大きく潜熱輸送量が大きいことが確認できる.

図-6より林地では観測気温よりも約 $3^{\circ} \mathrm{C}$ 程度地表面温度 が低いことが分かる．蒸発散量が小さく潜熱輸送量が小 さい不浸透地物等では観測気温よりも地表面温度が $5^{\circ} \mathrm{C}$ 以上程度高くなっていることが確認できる.

\section{6. むすび}

本論文は，都市流域において非常に複雑に形成され た個々の建物, 道路などの不浸透域, および公園, 畑地 などの浸透域を正確に表現できる高度な地物データ GIS を活用し，バルク式による熱収支式を用いて個別地物毎 の土地利用の違いおよび土㙵水分量の状態を考慮した潜 熱, 顕熱を算定できる TET モデルを構築したものであ る. 次いで, 神田川上流域において 2011 年の 1 年間の 個別地物毎の潜熱，顕熱および蒸発散量の算定を行った. その結果, 個別地物毎の潜熱, 顕熱および蒸発散量を推 定できることを確認し，実測值との比較によりその妥当 性を確認した. また, 神田川流域での空間的な蒸発散量 の違いおよび地物表面温度の空間分布について把握する ことができた.

本論文では地物は平面的に扱っており，大気層との鉛 直方向の熱のやりとりは考慮していない. 都市流域にお ける蒸発散量を精度良く推定するためには, 街路樹等の 詳細な地物区分の影響評価や建物壁面による放射の多重 反射等についての反映も必要である。また，本論文では 対象流域内の観測所が1箇所のみであったため, 気温, 風速等の気象条件の面分布については一様と仮定として おり，土地利用が同様であれば蒸発散量等に違いが無い 結果となっている. 今後は本論文で提案した蒸発散モデ ルの基本構造を踏襲しつつ，大気層との熱の移動の考慮， 複数地点での実測との比較等を行い都市流域における蒸 発散量を精度良く推定し，土地利用の変化による気温抑 制効果を評価可能なモデルの構築を行う予定である.

謝辞 : 本研究を遂行するにあたって，東京都アジア高度 研究「アジア都市圈における水問題解決のための適応策 に関する研究」(代表 : 河村明)の補助を受けました。こ こに記して深謝申し上げます。

\section{参考文献}

1) Hamon,W.R. : Estimating Potential Evapotranspiration, ASCE, HY3, paper 2817, 1961

2) Thornthwaite,C.W. : An approach toward a rational classification of climate, Geographical Review, Vol. 38, pp. 55-94, 1948

3) 竹下伸一・高瀬恵次 : 蒸発散サブモデルを導入した長期間流 出モデルの開発，水文・水資源学会誌, Vol.16, No.1, pp. 23-32, 2003.

4) 古賀達也, 河村明, 天口英雄 : 高度な地物データ G I S を用 いた都市流域における蒸発散モデルの構築とその適用, 土木 学会論文集B1（水工学），Vol.69, No.4, pp.I_1771-I_1776. 2013.

5) 天口英雄, 河村明, 高崎忠勝 : 地物データ G I S を用いた新 たな地物指向分布型都市洪水流出解析モデルの提案, 土木学 会論文集, Vol.63, No.3,pp.206-223, 2007.

6) 天口英雄 - 河村明 - 荒木千博 - 高崎忠勝 : 神田川上流域の地 物データを用いた洪水流出モデルの構築とその適用, 河川技 工学) , Vol.68, No.4, pp.I_505-I_510.

7) 天口英雄 - 河村明 - 高崎忠勝 - 中川直子 : 個別の地物情報を 考慮した密集市街地におけるTokyo Storm Runoff Modelの提 案，水工学論文集，第55巻, pp.S517-S522, 2011.

8) Amaguchi, H., Kawamura, A., Olsson, J. and Takasaki, T., Development and testing of a distributed urban storm runoff event model with a vector-based catchment delineation, Journal of Hydrology, No.420-421, pp.205-215. 2012.

9) 安藤義久・虫明功臣・高橋裕 : 丘陵地の水循環機構とそれに 対する都市化の影響, 第25回水理講演会論文集, pp.197-208, 1981

10) 近藤純正 : 地表面に近い大気の科学, pp.137-145, 2000.

11) 10)に同じ,p.141, 2000.

12) 10)に同じ, p.5, 2000.

13) 10)に同じ,p.143, 2000.

14) 10)に同じ,p.3, 2000.

15) 水文・水資源学会 : 水文・水資源ハンドブック,p.43, 1997.

16) 荒木千博 - 河村明 - 天口英雄 - 高崎忠勝 - 須藤正大 : 神田 川流域の地物データGISを用いた地下水涵養モデルの構築と その適用，河川技術論文集，第15巻,pp.371-376, 2009.

17) 鴨下泰典, 藤村和正, 高崎忠勝 : 井の頭池における水文観 測地下水位解析 : 土木学会年次学術講演会講演概要集, 第63 巻, No.02, pp.11-12, 2008.

18) 10)に同じ, p.75, 2000.

19) 藤田光一 ・伊藤弘之・小路剛志 - 安間智之 : 国土技術政策 総合研究所資料第299号 水物質循環モデルを活用した水環境 政策評価〜霞ヶ浦とその流域を対象として〜,p.34, 2006.

20)「都市小流域における雨水浸透, 流出機構の定量的解明」 研究会 : 都市域における水循環系の定量化手法一水循環系の 再生に向けて一,第二編 技術解説, p.58, 2000 .

21) 10)に同じ,p.41, 2000.

22) 健全な水循環系構築に関する関係省庁連絡会議 : 神田川流 域水循環系再生構想検討報告, p.5, 2003.

23) 東京都都市計画局都市づくり政策部広域調整課 : 東京都水 循環マスタープランの概要, p.2.

(2013. 9. 30受付) 